\title{
INVESTIGATION OF THE SOLUTIONS OF PRIZEN UNIVERSITY, EDUCATION FACULTY TEACHERS MATHEMATICS PROBLEMS
}

\author{
Prof. Ass. Münevver MUYO YILDIRIM*, Prof. Dr. Hülya GÜR** \\ "Prizren "UKSHIN HOTI" University, Faculty of Philology, munevvermuyo@gmail.com \\ **Ballkesir Universty, Faculty of Education, hgur@balikesir.edu.tr
}

\section{Article info}

\section{Article history:}

Accepted 16 December 2018

Available online 31 December 2018

Keywords:

Worksheets, Teacher Trainees, Problem Solving, Problem-Solving Skills, Problem Posing

\begin{abstract}
A b s t r a c t
The aim of the study was to examination of mathematical problem-solving skills and to determine the relationship of between problem posing and problem-solving skills of teacher trainees in Prizren "Ukshin Hoti" University, Faculty of Education in Kosovo. The results of this study are important because there is no a similar work in teacher training in Kosovo. For this aim, the case studies, qualitative research (case study), model was used. The research at the state Prizren "Ukshin Hoti” University has been established by Turkish Teacher trainers. These teachers' group was selected as a working group. The classroom teacher department NCT=26, Pre-school teacher department NPST $=27$ and physics-chemistry teacher department NPCT $=12$ teacher trainees were participated. The total number of trainers was 65 . The data were collected by semi-structured interview form and worksheets in this study. Rubrik and descriptive statistics were used as an analyzing instrument. In conclusion, the levels of problem-solving skills of teacher trainees have been determined and recommendations for the development of these levels have been included.
\end{abstract}

\section{Introduction}

21st century. the characteristics expected from the human being have changed with the age (Koenig, 2011). The basic objective is to teach problem solving and logical thinking, to create alternative solutions in the face of problems. It is impossible for mathematics education not to be affected by changing educational approaches (Umay, 2004). The students who are trained with the traditional curriculum think that knowing a certain rule or formula will be enough to solve the problem, and how quickly they can show what they know with the paper pen. Students memorize what they have learned at school, while preparing for examinations, while solving questions similar to exercise questions, blinding successful students. Although the importance of creativity in mathematics education is emphasized, students think that mathematics learning is based on rote even though they want to solve similar problems without solving problems and then solve them (Ersoy and Gür, 2004). However, teachers are expected to have important tasks in the classroom where problemsolving approach education is given. Teachers can understand the problems experienced by children in problem solving by observing in the classroom. Teachers play a corrective and guiding role in providing students with an accurate perspective in the analysis of the problems they face. Assessing problem solving in the classroom is a complex and difficult task. While some students determine the right answer with wrong logic, some cannot achieve the result of simple errors by using the most accurate strategies. The problem-solving process requires thinking at every stage of the problem. The problem-solving process shows that problem solving is not only a result-oriented 
skill (Çakmak, 2003).

For effective mathematics teaching, it is important to know how students learn and to create environments where students can gain the skills necessary for the future and develop their skills. In this way, teachers should provide the students with the opportunity to express themselves in a comfortable environment, and to provide an environment for their personal development. Such an environment is possible with qualified teachers (Beşoluk and Önder, 2010). A number of teaching strategies should be considered in the successful implementation of mathematics teaching. The student must be an active participant in the teaching process. The knowledge, skills and thoughts of the student should be used to make sense of new experiences and situations. Therefore, the problems chosen in the mathematics lesson should be interesting and interesting about the subjects that students need in their daily life and the activities they do at school. Students should be interpreted by interpreting the new information they have gained by associating them with their previous knowledge. In other words, environments should be created to provide the individual meaning of the students. Class discussions should be used to create common mathematical truths and meanings. Therefore, the teacher should come to the class by planning wellstructured activities (MEB 2004).

It is stated that the work sheets are important tools that involve the steps of the process in which the students specify what they should do, help them to establish their own knowledge in their own minds and at the same time ensure the participation of the whole class in the given activity. Among the reasons that make the use of the worksheets attractive are the fact that the teachers move more easily in the classroom and allow the students to learn the basic information more actively, to allow students to work at their own pace, to eliminate the time loss, to meet the needs of the students in different abilities and to provide responsibility to the students. and to be effective on low motivated students (Sharma, Millar and Seth, 1999). The work sheets can be applied both individually and as a group, and it is one of the funs learning materials of both student teachers and students, who takes the students out of passive knowledge as a buyer and constructs the knowledge of each individual.

\section{Teacher Education in Kosovo}

The Republic of Kosovo is a country where many communities live together and multilingual education is carried out. The communities in Kosovo have lived together for a long time and have continued their right to receive education in their mother tongue, except for some periods in which they lived. It is of great importance for the communities living in Kosovo to receive education in their mother tongue. Today, the people of Kosovo give more importance to education. Improving the quality of education in Kosovo and the great help of some countries, including the Republic of Turkey in particular for the development of human potential, and it is possible to see the investment project. In Kosovo, there is a need to provide training in different fields in order to complete the missing cadres, and to have teachers who are different in their fields and not to have to give lectures in different fields. Therefore, the upbringing and employment of teachers in different areas in Kosovo has become an important issue (Ergül, 2009)

Since Kosovo became an autonomous region in 1990, it has worked in cooperation with the United Nations and the European Union on education and teacher training in Kosovo. Prizren "Ukshin Hoti" University is located in Prizren which is the region where Turks live in Kosovo, was connected to Pristina University in 2002. The Faculty of Education has trained teachers for 2 years until 2002 and then for 4 years after 2002 (Saqipi, 2008). Prizren "Ukshin Hoti” University, Faculty of Education is the first section of Turkish education as "Classroom Teaching" section has been. The department is 4 years old and shows parallels with the Albanian and Bosnian classrooms in the faculty of education (Çelik, 2009). As of the 2010-2011 academic year, the Faculty of Education in Prizren "Ukshin Hoti” University, which is affiliated to the University of Prishtina, is leaving the University of Prishtina, under the name of Faculty of Education of Prizren "Ukshin Hoti" University. In the Faculty of Education in the department is changed and the lack of attendance of the permanent staff.

The aim of this study is to investigate the problem-solving skills of pre-service teachers, preschool teachers and physics and chemistry teachers. This study on teacher training in Kosovo will be the first to be a source of similar studies on teacher training.

\section{Research Significance and Purpose}

Mathematics course, memorizing the concepts seen in the course, the relationship between concepts and processes to be similar to a course out of the concept and the process of establishing a meaningful link between the relationship and to include the connection with the current examples. Real learning is available with teaching environments that each individual adopts in his own mind. Teachers and teacher candidates await important responsibilities to keep up with changing curricula. It shows the 
importance of qualified teachers and pre-service teachers with the development and application of work sheets and activity papers to keep the students active. It is important for the students and teacher candidates to be inquisitive and thinking about the activities in the classroom environment in order to gain the ability of critical thinking. The education and training environment should be enriched with student-centered education, the teacher should act as a guide and an observer, the students should be in constant communication with their teachers and spend time in the classroom (Çetinkaya, 2011). The aim of this study is to investigate the relationship between teacher candidates' skills in solving math problems and problem building.

\section{Research Problem}

As case we take "Prizren "Ukshin Hoti" University, Faculty of Education" which was investigated the effect of the teacher candidates studying Turkish on the problem solving and problem forming skills of the learning activities based on the study sheets.

\section{Methods}

In this part of the study, the model of the study, the study group, data collection and analysis are included. It is a qualitative research by obtaining the work sheet file and semi-structured opinions applied for the examination of problem-solving skills of prospective teachers. The study model was selected and used. This model is considered as one of the relational survey models by Karasar (1984).

\section{Study Groups}

The study was carried out with a pilot study in a public Prizren "Ukshin Hoti” University, where Turkish language education was given, and in 2013-2014 academic years, Turkish-educated (NT=174) teacher candidate. The study group of the study consisted of Teacher Training Department of the Department of Primary School Teaching, Department of Primary Education NPS=26, Department of Turkish Language Teaching NPreSch=27, Department of Preschool Teacher Education and Department of Physics-Chemistry Education NPhC $=12$.

\section{Data Collection}

A preliminary information seminar, interview (interview I and interview II) and study sheets were used as data collection tools. The seminar is given on 4 hours course on "Problem-Based Problem Solving". At the seminar; the importance and importance of problem solving in mathematics teaching; strategies and techniques for problem solving in mathematics teaching; problem solving and benefits of installing, setting up and solving problems in the world and in Turkey, studies, TIMSS and PISA exam and contents, information is given about. At the end of the seminar, prospective teachers were interviewed. Participants Each of the three volunteers who participated in the seminar and participated in the seminar attended the seminar.

Interview I contain 4 questions with semi-structured open-ended. The aim of interview I was to express the opinions of prospective teachers about the problem solving and problem-solving seminar. Interview II was conducted with 3 people who were not willing to attend the first interview and who were willing to do the activities and who were also volunteers. Interview II consists of 3 semi-structured open-ended questions. The aim of Interview II is to determine the prospective teachers' views on problem solving and problem-solving instruction in mathematics education, and their opinions on the necessity of problem solving and how to make them better. Interview with each pre-service teacher lasted for 10-15 minutes.

Nine questions were included in the PISA 2000, PISA 2003 and PISA (pisa-sq.acer.edu.au, 2010) questions. One question was created by the researcher. 10 working sheets were created. In preparing the questions, it is taken into consideration that they are intertwined with daily life and that they are one of the questions containing problem solving strategies. For each of the worksheets, they were consulted with expert opinions and prepared for implementation.

Table 1. Rubric of Working Leaves

\section{WL-1: Apple Tree Garden}

Full Score: Examines the shape, visualizes the problem with a problem-solving strategy, achieves the correct result;

Partial Score: Rounding result without action and explanation - table (1 point).

Zero Points-Blank: Different answers-false-free ( 0 points). 


\section{WL-2: Step Model}

Full Score: Draws the shapes for the desired steps how many squares are necessary to discover their own environment and use the formula for the fields and selecting the unit (reference 1br, 2 br) makes the calculation; the correct result is 10 ; With $\mathrm{C}=4 \mathrm{a}$ and $\mathrm{A}=\mathrm{a} 2$ (2 points).

Partial Score: Shapeless gives only the correct answer for Step 4 other desired answers are missing or incorrect (1 point).

Zero Score or Blank: Answer or blank (0 points).

\section{WL-3: Let's Make Blocks}

Full Score: Counting the small cubes in the figure, A, B, C, respectively, 8, 12, 27 small cubes are required for the field and the area, volume formulas with the reference measure makes self-selected. In the other question, it is expected that 120 small cubes are needed, and are expected to calculate surface area and volume similarly (2 points).

Partial Score: The figure in the figure represents the first two or the first three correctly, but for others, incorrect answers and other actions are missing (1 point)

Zero Points or Blank: Missing answer is missing ( 0 points).

\section{WL-4: Bookshelf}

Full Score: Considering the items in the carpenter's store, grouping and counting the required number of items for a library, giving the correct answer to 5 books with the correct result ( 2 points).

Partial Score: Those who express the correct result without any explanation (1 point).

Zero Score or Empty: Those who are completely wrong result or blank ( 0 points).
WL-5: Carpenter

Full Score: Based on the environmental formulas of the shapes in mathematics, think of the appropriate design for the board of $32 \mathrm{~m}$.

YES, correct answer (2 points).

Partial Score: The second design is confusing, only YES -? YES-YES can explain for three; the second is unanswered and without explanation (only 1 point).

Zero Score or Blank: Two or fewer correct answers or blank (0 points).

\section{WL-6: Numbered Cubes}

Full Score: answers to explain this method as it uses a method which shapes the sum of opposite faces sevenNO-YES-YES-NO-yielded (2 points).

Partial Score: It was able to answer at random without explanation and to give three correct answers. Like YES-YES-YES-NO ... (1 point).

Zero Score or Blank: Unable to give up to two correct answers or empty (0 points).

WL-7: Staircase

Full Score: The arithmetic operation in mathematics, using the necessary operations with the Pythagoras relation, refers to the height of each of the 14 steps in the staircase as $18 \mathrm{~cm}$; The right approach for other dresses ( 2 points).

Partial Score: The process is incorrect or missing but the correct result is $18 \mathrm{~cm}$; description or answer missing (1 point).

Zero Points or Blank: Missed path was followed and the response was incorrect or empty (0 points).

\section{WL-8: Skateboard}

Full Score: The skateboard board lengths given in the table are given as $40,60,65,82,84$, the width is expressed as the longest skateboard 1680, with the shortest skateboard with wheel set diameters of $20 \mathrm{~cm}$, considered to be $20 \mathrm{~cm}$ for each length; The surface lengths are expressed on the basis of calculations with the formula (2 points).

Partial Score: Without processing, only the short and long skateboard is correct and other answers are missing (1 point).

Zero Points or Blank: Incorrect result is missing or empty ( 0 points). 


WL-9: Rock Concert
Full Score: First, the Rock concert area is calculated and is
expressed in the correct order of reasoning with
20,000 followed by 5000 and 80,000 for the
most recent situation ( 2 points).
Partial Score: The correct result for the first two is incorrect
for the last situation, the transaction may be
missing (1 point).
Zero Points or Blank: Incorrect result, one of which may be
correct or missing operation ( 0 points).
WL-10: Sinan Pasha Mosque
Full Score: Minaret size, the ladder length of the correct
calculated by proportion, self-selected reference
size of the mosque's floor area and the surrounding
area (2 points).
Partial Score: The minaret is calculated by the ladder layer
determined by itself, the mosque has failed to
calculate or calculate the area around the mosque
incorrectly (1 point).
points).

\section{Findings and Comments}

\subsection{Findings of Study Work Sheets of Teacher Candidates}

From the qualitative data of the study, participants' answers to 10 study sheets were read and each stage of the problem was evaluated according to the level specified in the scoring key. Candidates of physics and chemistry teaching from 10 related study sheets applied individually to teacher candidates 8; Preschool teacher candidates 22 and 23 class teacher candidates completed the work sheets and a total of 53 pre-service teacher work sheets were collected.

Table 2. Receive Score Chart from Worksheets

\begin{tabular}{|l|l|l|l|}
\hline Worksheets & $\begin{array}{l}\text { Full } \\
\text { Points }\end{array}$ & $\begin{array}{l}\text { Partial } \\
\text { Points }\end{array}$ & $\begin{array}{l}\text { Zero } \\
\text { Points }\end{array}$ \\
\hline WL-1 & 19 & $\mathbf{2 5}$ & 9 \\
\hline WL-2 & 6 & $\mathbf{4 2}$ & 5 \\
\hline WL-3 & 1 & $\mathbf{2 8}$ & 24 \\
& & & \\
\hline
\end{tabular}

\begin{tabular}{|l|l|l|l|}
\hline WL-4 & 15 & $\mathbf{2 8}$ & 10 \\
\hline WL-5 & $\mathbf{2 5}$ & 6 & 22 \\
\hline WL-6 & $\mathbf{4 4}$ & 4 & 5 \\
\hline WL-7 & 0 & $\mathbf{4 9}$ & 4 \\
\hline WL-8 & 7 & 8 & $\mathbf{3 8}$ \\
\hline WL-9 & 18 & $\mathbf{2 5}$ & 10 \\
& & & \\
\hline WL-10 & 0 & 5 & $\mathbf{4 8}$ \\
\hline
\end{tabular}

Examining the study of WL-1, WL-2, WL-3 and WL-4; it was observed that pre-service teachers received a score between full score and partial score. The candidates are expected to realize the steps they will take to solve the work sheets;

- $\quad$ set up a new problem based on the number and operations given,

- hey can create a problem by changing open-ended problem expression, understand the problem,

- identify the strategy while solving the problem,

- it has been found that they can use more tables, shapes and graphics instead of using mathematical language.

Below are some examples of the work sheets of prospective teachers. 


\section{Examples of apple tree garden activity of teacher candidates}

PHC2 teacher candidate's answer:

$\mathrm{PS}_{18}$ teacher candidate's answer

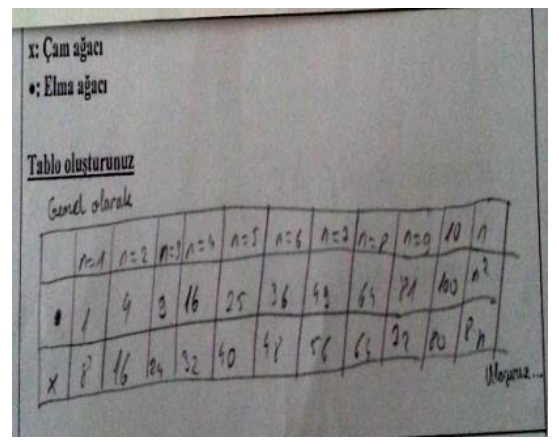

$\mathrm{PRESCH}_{8}$ teacher candidate's answer

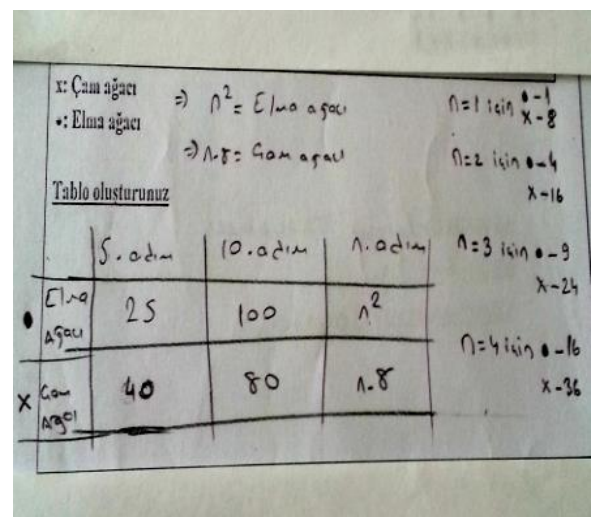

It is seen that PHC2 pre-service teacher from Physics-Chemistry department takes the table for the first activity and produces solutions for the problem. The generalization and calculation process is shown on the same table by answering correctly. It is seen that PS18 pre-service teacher from the Department of Primary Education produces a good solution for the apple garden activity and has reached the right result by tabulating the 5 th and 10th steps in the problem. The solution of the preschool teacher candidate's answer with a simple, straightforward mathematical expression language can also provide solutions to other similar problems.

The PRESCH8 pre-school teacher had partially correct answers to the candidate's first activity. Only for the 5th and the 10th step, using the demonstration solution strategy has reached the correct result.
However, he could not reach a generalization. The candidate has difficulty in mathematically expressing the problem, $n$. It is seen that in order to produce mathematical form for apple and pine tree, it is weak.

\section{Examples of candidates for carpenter activity}

$\mathrm{PHC}_{1}$ teacher candidate's answer:

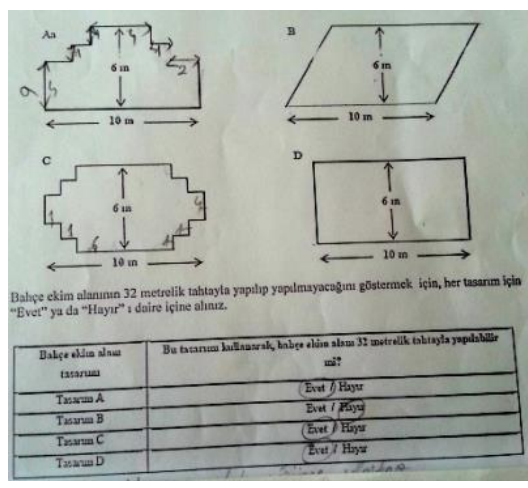

$\mathrm{PRESCH}_{8}$ teacher candidate's response

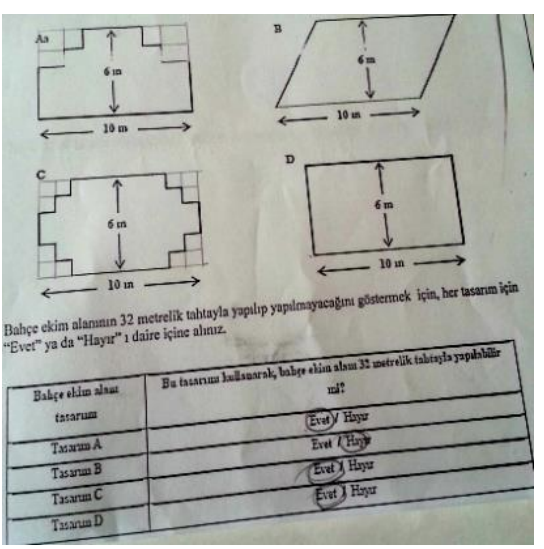

$\mathrm{PS}_{23}$ teacher's answer

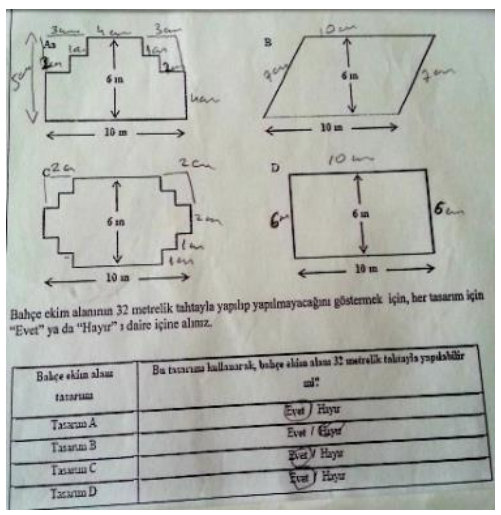

PHC1 teacher candidate from the department of PhysicsChemistry teaching tried to explain the relations between the key 
components of the problem and the designs by using mathematical operations. With the mathematical result approach, he produced the right solution for the designs.

In the pre-school teaching department, PRESCH8 pre-service teacher made the simplification required by the problem at a very good level, and it was seen that the figures were completed with drawing according to the data and answered by seeing whether they confirmed the result. The answers are also the desired solution to the problem.

She drew the designs given by the Department of Primary School Education by completing the shapes according to the 32 square meters board. He has dealt with all the components of the problem correctly and successfully completed them.

Similarly, for the Sinan Pasha Mosque, which is in the problem of daily life, the prospective teachers had a hard time answering, 5 teacher candidates had made part of it, and 48 teacher candidates left them wrong or left blank.

\section{Examples of teacher candidates related to Sinan Pasha Mosque activity}

$\mathrm{PHC}_{3}$ teacher candidate's answer

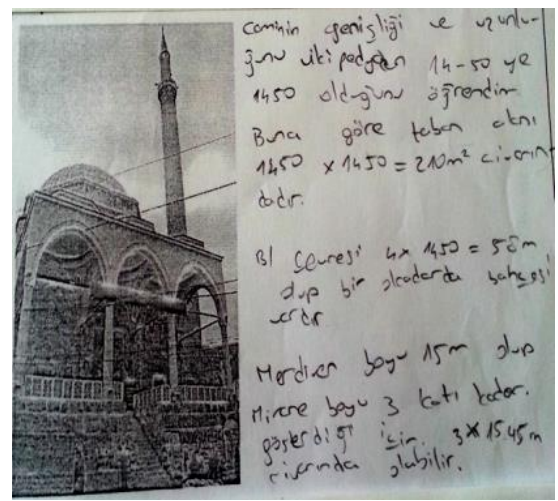

$\mathrm{PS}_{12}$ teacher candidate's answer

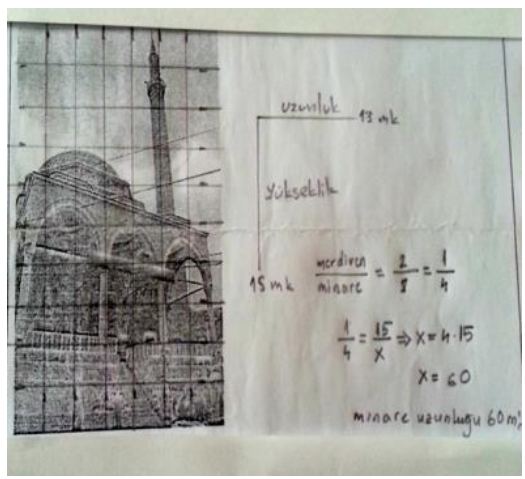

In the Physics-Chemistry Teaching department, it is seen that the mosque activity given as PHC3 pre-service teacher visually understands the problem, but it does not fully reflect it during the process.

In the Department of Primary Education, the ratio of minaret height to ladder and the minaret length in the direction of the process was divided into squares by the squared PS12 teacher candidates in the official mosque activity. Since the mosque cannot determine the mathematical operations related to the floor area and its surroundings, it is seen that the interpretation is incomplete for the solution.

Sinan Pasha Mosque activity was the weakest work in the file. The overall number of teacher candidates did not reach the correct result.

The study sheets of 53 pre-service teachers who completed and delivered the study sheets were examined. Teacher candidates:

- 3 pre-service teachers received 15-16 points out of 20;

- It has been observed that 21 pre-service teachers score between 10 and 10 points.

- $\quad$ There are 29 prospective teachers

The success points and percentages of teacher candidates according to departments are;

- 8 out of 10 physics and chemistry teacher candidates scored 10 and over (63\% success) and 3 scored less than 10 .

- 22 out of 10 pre-school teacher candidates have scored 
10 and above (14\% success) and 19 out of 10 .

- 16 out of the total of 16 primary school teacher candidates scored 10 points and above (70\% success) and 7 out of 10 points.

\section{Findings from interview forms}

In this section, the analysis of the results of the prospective teachers' answers to the four open-ended questions in the Interview-I form has been qualitatively interpreted and the reflective opinions of the prospective teachers are presented below. When the answers of the teacher candidates were examined, it was seen that the answers were collected in 6 categories. Based on the expressions of prospective teachers, Figure 1 below is formed.

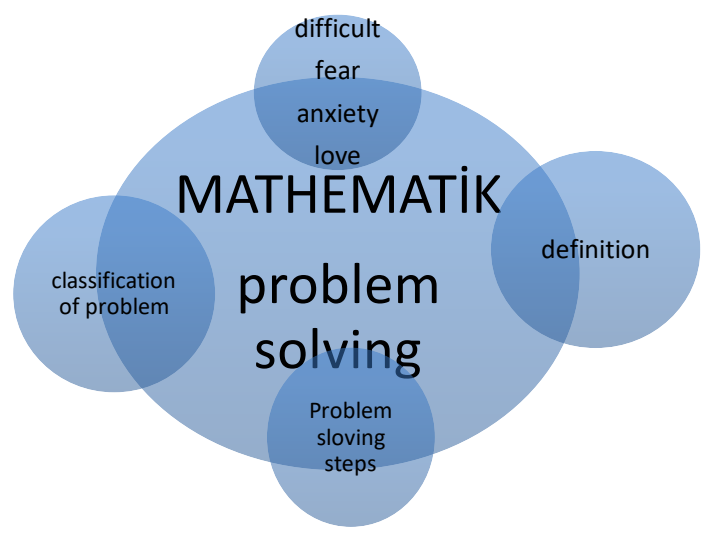

Figure 1. Teacher candidates' opinions on problem solving activities-I

Prospective teachers related the problem with mathematics, have understood the meaning, have learned about the problem-solving steps, and the types of problem solving. They did not understand the problem, did not know the problem-solving steps, cannot classify problems in mathematics to solve problems and therefore fear and anxiety and they did not like the result of mathematics.

The analysis of the results of the pre-service teachers' responses to the three open-ended questions in Interview-II form was interpreted qualitatively. When the opinions of all the candidates are examined, it is contradictory with the opinion that the education they take about problem solving and problem solving in the university education is the problem of problem solving and problem solving in middle school and high school. Based on the expressions of prospective teachers, Figure 2 is formed.

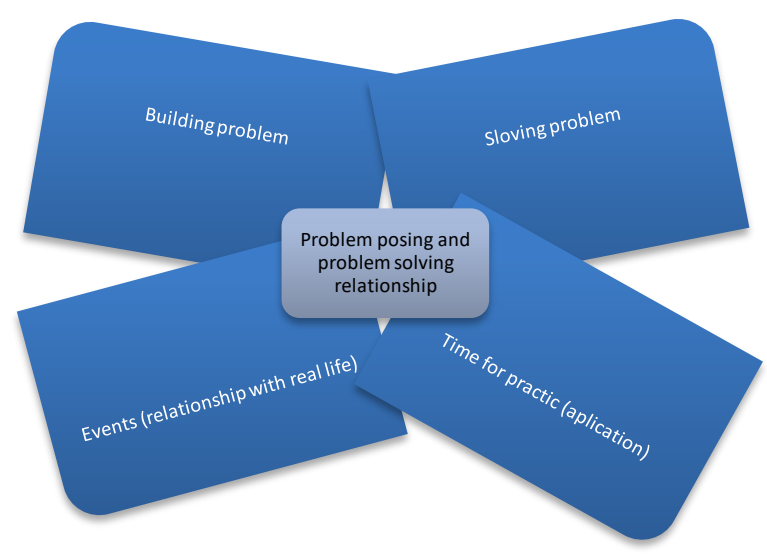

Figure 2. Teacher candidates' views on problem formulation and problem solving II.

Candidates stated that they could not get enough information about problem solving and problem solving in university education. They stated that the pre-service teachers had focused on the verbal problems including the four procedures in the mathematics textbooks related to problem solving and problem solving in university education.

It is seen that pre-service teacher candidates and pre-school teacher candidates and pre-service teacher candidates have similar opinions about the problem. In the views of the candidates, the students expressed the problem clearly and briefly in order for the students to understand the problem well, they understood the problem well, and stated that they would gain experience in forming similar problems while revealing the necessary knowledge-skills for the solution.

\section{Result and Conclusion}

After the seminar on Problem-Based, Problem Solving Training in which was applied in the context of the research, the file containing 10 work sheets which were kept separate to each candidate, according to the results of the teacher candidates before and after the application of the 10 Problem Solving after in the views of the non-very high level of teacher candidates who have grown in their views it can be explained by the dominance of traditional education approach. In addition, in mathematics lessons that teacher candidates see in the school, it can be explained by the effect of the teacher's adherence to mathematics textbooks. Undoubtedly, the study included prospective teachers. Because of their long and specific educational background, it may 
be difficult to change the learning in this long-term education process. It is possible that the program to be implemented at earlier ages may lead to differentiation in the results. In the general evaluation of the study sheets applied to prospective teachers, it was seen that the performance of the teacher candidates of the Department of Physics-Chemistry Teaching and Primary Education Department was higher than that of pre-school teacher candidates. At the end of the study, teacher candidate's problem in the problem-solving process, thinking about what the process and when they read the problem, what information they need to reflect the information, although partially reflect the simplification form, logical explanation, prediction and control, systematic study and making table, problem solving strategies were effective.

Open-ended questions in the study of the problem of solving problems in the open-ended questions by considering the similarities and differences of the many steps to try to achieve only the result of the result, verbal interpretation of the different reasoning in the questions to be asked that the teacher candidates in the theoretical knowledge of the problem solving and found out the theoretical knowledge and practices although they have seen, the traditional teaching concept they have grown in is dominant and the problems solved during teaching are thought to be not related to real life.

At the end of the work sheet, open-ended questions and modeling problems, the candidates try to reach the result by mathematical operations, they have difficulty in making necessary explanations, they cannot make enough interpretations about the reason, they give realistic answers in interpreting the problems and they have difficulty in forming similar problems because they cannot solve the problem. The fact that physics-chemistry teaching department cannot be realized is quite thoughtprovoking. Candidates who work in different departments have been imitating each other and have similar deficiencies and errors in the work sheets. According to the results of the study, it can be said that there is no significant difference between the mathematics literacy levels of the prospective teachers in all three sections, and the experience of solving problems in mathematics will take time to develop mathematical literacy levels. This was found to be inadequate in questioning exactly what was required in the problem and lack of knowledge in mathematics.

In the opinions of prospective teachers of Physics-Chemistry Teaching department, the main reason for the difficulty of mathematics and problem solving is the fact that mathematics lessons are taught by traditional teaching method. Teachers of Physics-Chemistry Department emphasized that mathematics literacy should be given importance in mathematics education and that questions containing real life problems may contain more than one answer. Because pre-service teachers were low in mathematics literacy in high school and lower grades, and the university was not offered any excuses, pre-service teachers had difficulty in expressing themselves in the application of mathematical worksheets.

As a result, it was found that the study on mathematics literacy, which includes the development of mathematical problemsolving and problem-building skills of prospective teachers, was a first in Kosovo and there was a positive effect on the problem solving and formation of pre-service teachers' mathematics literacy.

According to the findings obtained in the research, some suggestions can be made to the researchers;

- Similarly, it may be the basis for teachers to work with teachers, to determine the problem-solving skill levels of teachers in the development process, and to develop curriculum for teachers according to these results.

- A similar study could be done in order to support prospective teachers working in groups.

- Instead of giving information about problem solving and problem solving and work sheets to the trainees and teachers, studies can be carried out to prepare and evaluate the work sheets and thus to see their deficiencies.

- In-class seminars should be given to all mathematics and mathematics teachers who work in primary, secondary and high school.

- Students who are considered to be unsuccessful in the mathematics course should be encouraged to improve their achievements with mathematical literacy related scenarios and activities and to develop a positive attitude towards mathematics.

\section{References}

1. Beşoluk, Ş. ve Önder, İ. (2010). Öğretmen Adaylarının Öğrenme Yaklaşımları, Öğrenme Stilleri ve Eleştirel Düşünme Becerilerinin İncelenmesi. ilköğretim online, 9(2), 679-693. 
2. Çakmak, M. (2003). Matematik Derslerinde Problem Çözme Yaklaşımının Değerlendirilmesi. Matematikçiler Derneği Bilim Köşesi [online]. (12. 05. 2014), www.matder.org.tr.

3. Çelik, S. D. (2009). Kosova'da Türkoloji Eğitimi. International Journal of Central Asian Studies Volume 13. [online]. (31. 07. 2015), (http://www.iacd.or.kr/pdf/journal/13/Binder11.pdf.

4. Çetinkaya, Z. (2011). Türkçe Öğretmen Adaylarının Eleştirel Düşünmeye İlişkin Görüşlerinin Belirlenmesi. Ahi Evran Üniversitesi Kırşehir Eğitim Fakültesi Dergisi, 12(3), 93-108.

5. Ergül, H. F. (2009). Kosova' da Türkçe Eğitim ve Sınıf Öğretmeni Yetiştirme İhtiyacı. Dicle Üniversitesi Ziya Gökalp Eğitim Fakültesi Dergisi, 13, 9-51.

6. Ersoy, Y., ve Gür, H. (2004). Problem Kurma ve Çözme Yaklaşımlı Matematik Öğretimi-I: Öğretmen Eğitim Denemeleri ve Bazı Sorunlar. Matematikçiler Derneği Bilim Köşesi [online]. (21. 08. 2013) URL: http://www.matder.org.tr/bilim/hgyepk.asp? ID $=82$

7. Karasar, N. (1984). Bilimsel Araştırma Yöntemleri, 2. Baskı, Ankara: Nobel Yayın Dağıtım.

8. Koenig, Judith A. (2011). Assessing 21st Century skills: Summary of a workshop. Washington, DC: National Research Council.

9. MEB. (2004). Milli Eğitim Bakanlığı. İlkögretim Matematik Öğretim Programı [online]. (11. 03. 2014), http://www.meb.gov.tr

10. Miles M. B. and Huberman, A. M. (1994). Qualitative Data Analysis, London: Second Edition.

11. PISA, (2010). [online]. (12.01.2014) www.oecd.org/pisa/home.

12. Saqipi, B. (2008). Teacher Education In Kosovo International Influence In Shaping It And Obstacles In Making It Work In The Local Context. TEPE 'nd Annual Conference Teacher Education Europe Mapping The Landscape and Looking to The Future. Faculty of Education, University of Ljubljana, Slovenia, (Thursday 21 - Saturday 23 February 2008). [online]. (31.07.2015), http://www.seeeducoop.net/education in/pdf/high-educ-kos-enlt02.pdf.

13. Sharma, D., Millar, R. and Seth, S. (1999). Workshop tutorials: Accomodating student centered learning in large first year university physics courses. International Journal of Scientific Education., 2, 839853.
14. Umay, A. (2004). Matematik Eğitiminde Değişim. Matematikçiler Derneği Bilim Köşesi, [online]. (31. 07. 2015),

URL: http://www.matder.org.tr/bilim/aumed.asp?ID=68.

15. Yıldırım, A. ve Şimşek, H. (2008). Sosyal Bilimlerde Nitel Arastırma Yöntemleri, Ankara: Seçkin Yayıncılı. 